\title{
1 Hour Q-Time as a Preventive Effort of Juvenile Delinquencies to Prepare the Golden Generation of Indonesia 2045
}

\author{
Shovi Maryam, Fathiyatul Ummah, Ahmad Munjin \\ Nasih \\ Universitas Negeri Malang \\ Malang, Indonesia \\ shovimaryam@gmail.com
}

\author{
Ahmad Faris \\ Department of Usuluddin \\ Faculty of Islamic Studies \\ Al-Azhar University \\ Cairo, Egypt
}

\begin{abstract}
The current major problem faced by young people in Indonesia is juvenile delinquencies which increase every year. There are some factors behind these problems, such as broken home and mainly lack of parents' control. This scientific paper aims to describe the idea of creating a new innovative program to increase the harmonization of a family with character education named 1 Hour $Q$-Time as the preventive effort of juvenile delinquencies to prepare the golden generation of Indonesia 2045. 1 Hour Q-Time is the small gathering with each member of the main family in one hour every day. Parents ask for their children's activities, what are their problems, how to gain their dreams, advise them wisely without being judgmental, give them solutions to their problems, and tell them inspiring stories. The methodology used in this scientific paper is based on the process of reviewing the related literature and or previous research findings which are taken selectively from accredited journals, textbooks, instructional media, articles, and some texts related to the topic. Based on the results of the analysis and the synthesis, it has many values of character building and education integrated into every detail and step.
\end{abstract} family

Keywords - character education, quality time, Indonesia Emas,

\section{INTRODUCTION}

The current major problem faced by young people in Indonesia is juvenile delinquencies which increase every year. There are some factors behind these problems, such as broken home and mainly lack of parents' control. This scientific paper aims to describe the idea of creating a new innovative program to increase the harmonization of a family with character education named 1 Hour Q-Time as the preventive effort of juvenile delinquencies to prepare the golden generation of Indonesia 2045. 1 Hour Q-Time is the small gathering with each member of the main family in one hour every day. Parents ask for their children's activities, what are their problems, how to gain their dreams, advise them wisely without being judgmental, give them solutions to their problems, and tell them inspiring stories. The methodology used in this scientific paper is based on the process of reviewing the related literature and or previous research findings which are taken selectively from accredited journals, textbooks, instructional media, articles, and some texts related to the topic. Based on the results of the analysis and the synthesis, it has many values of character building and education integrated into every detail and step.

Globalization supported by the information technology so rapidly make the life more complicated and unpredictable [1]. Children and adolescents are the people who will determine the future of this nation. God has given a strong body, healthy mind, and many opportunities to them. They are the prospective stakeholders of golden generation of Indonesia 2045 that is required to have intellectuality, emotionality, and primarily spirituality to build Indonesia to be a developed and prosperous country.

The facts nowadays are not corresponding with the hope of the nation. The kinds of juvenile delinquencies become the causes. The juvenile delinquencies consist of porn (pornography addiction), abortion, free-sex, smoking, drugs, bullying, and illegal street racing and brawl [2]. The number of such delinquencies increases every year.

These results are also the same with the results of the study of National Commission of Children Protection (Komisi Perlindungan Anak Indonesia/KPAI) [3] in 33 provinces in January-June 2008 that concluded four things, first, 97\% of junior high and high school adolescents had ever watched a porn film. Secondly, $93.7 \%$ of junior and senior high students had kissed, done genital stimulation and oral sex. Third, $62.7 \%$ of junior high school adolescents were not virgins, and the last $21.2 \%$ of adolescents admitted that they did abortion [4]. The data certainly increases every year. Besides, the Central Bureau of Statistics [5] reported data from Supenas that mentioned the crime victim among children in 2011 amounted to 385,470 . Then, in 2012, it amounted to 348,341 . The data drastically reduced in 2013 which amounted to 268,371

Based on the estimated statistics from BKBN [6], there are about 2 million cases of abortions that occur every year in Indonesia. Based on the data from the National Narcotics Agency (Badan Narkotika Nasional/BNN) [7] in 2006, there were 2000 adolescents rehabilitated in hospitals. This figure increased in 2011, BNN [7] noted that 110,870 junior high and high school students became narcotics consumers. 
In addition, the National Commission for Children Protection (Komnas Anak) noted that in 2014 there were 89 suicides. Nine cases occurred in children aged 5-10 years old, 39 cases occurred in children aged 12-15 years old, and 27 cases occured in children aged 15 years old (www.nasional.sindonews.com). Ironically, in Bengkulu, a 14years-old girl was raped and killed by 14 teens in 2016 due to pornography addiction [8].

Several factors cause juvenile delinquencies, such as broken home, mainly the lack of parents' control, the negative impact of social media, and unhealthy environment. According to [3], 3682 correspondents responded that the acts of violence were mostly affected by families and the environment. Besides, families, community groups and mass media also can form patterns of memory systems reflected in individual's behavioral habits through imitation and modeling. The family becomes an important factor in the development of children psychology. Parents provide the basic emotional and moral life of children. The family's emotional life can guarantee the children's emotional life in their personal life [9].

Problem behavior theory explains that the formation of adolescent deviant behavior is influenced by three interrelated aspects. The first aspect is personalities that include individual values, expectations, and beliefs. The second aspect is the environmental system received by adolescents, such as in the family environment or peers. The third aspect is the behavioral system that is the way the teenagers choose to behave in everyday life [10].

The writers offer these programs; those are the implementation of family's harmony movement that is 1 Hour Q-Time. These programs were designed by observing juvenile delinquencies which are higher and higher. We believe if we do this concept in our environment, family periodically and thoroughly, will impact positively to create a harmonious family to prevent juvenile delinquencies so that the numbers of juvenile delinquencies in Indonesia can decrease. Within the long period, this program supports creating noble characteristic of Indonesian Golden Generation 2045.

\section{1) The Role of Family to Build Good Attitude and Character \\ Based on the Law number 52 of 2009, a family is a small unit in the society that includes husband and wife, or husband, wife and their children, or father and his children, or mother and her children. The growth of the family is an effort to actualize a qualified living family in the good environment.}

The success in actualizing the equivalent both growth of society and development of citizen and their family quality will fix all aspects and construct the dimency and society life to be better, independent, and also able to live with the other nations and able to fasten the actualize of frequented development [11].

The strongest evidence is the parent's role in supporting their children's cognitive development, especially for preschool children (Goodson, 2005). Responsive parenting is one of the aspects of parenting most frequently described when we try to understand the function of the environment playing in children's development [12].
Humans are not shaped by the environment, but by the way of interprating the received environmental messages. The children's personality is firstly formed based on the closest environmental messages, i.e. family communication. During their growth and development, communication between parent and child is a media to how they will act in the surrounding environment.

Effective communication [13] could reveal five things: understanding, happiness, good morals, good relationship, and attitude. The facts found that the behavior and communication of parents with their children have reflected the existence of basic moral values [14].

\section{B. Indonesian Golden Generation 2045}

Talking about Indonesian Golden Generation 2045 relates to the elements of character education of the nation. The characteristics of Golden Generation 2045 are the main strength to build NKRI to be a big nation, which is effectively getting advance, glorious and prestigeious. Character education could be done by two approaches. They are practice approach and essential approach. Practice approach trains good characteristics for pupils. Essential approach prepares attitude as the home of characteristics. Kemendikbud the Ministry of Education and Culture made the character education design by making a list of good characteristics which are the pupils have to implement. There are eighteen characteristics for character education and there are nine characteristics for anti-corruption education.

\section{The Golden Generation of Indonesia 2045}

Education itself is a media to reach knowledge and wisdom to live the life and create an excellent life for human being. Related to character education, education terminology is called a process of accumulating the good knowledge, attitude, and action. Education begins with building the awareness, feeling, caring, intention, knowledge, beliefs and habits formation [15]. The concept of character education in Table 1. The character is not taught but it is a habitual formation, for example, internalizing values, selecting good choice, doing them as habits, and providing examples; 2. Educating character to youth has to involve the youth situation and condition. 3. In education, some issues that should be considered are; learning situation, learning process, learning materials, and learning evaluation. 4. Character education is a never ending process.

TABLE I. CHARACTERISTICS OF CHARACTER EDUCATION:

\begin{tabular}{|l|l|}
\hline 1. Religious & 10. Nationalism \\
\hline 2. Honest & 11. Loving devotion to fatherland \\
\hline Tolerance & 12. Appreciating achievement \\
\hline Discipline & 13. Friendly/communicative \\
\hline Work-hard & Peaceful \\
\hline 6. Creative & Reading addictive \\
\hline 7. Independent & 16. Caring of environment \\
\hline 8. Democratic & 17. Caringof social life \\
\hline 9. Curiosity & 18. Responsible \\
\hline
\end{tabular}


.In 2045, Indonesia will be sustainably having bonus demography which is very profitable in various sectors. The generation which is expected to play a significant role in the year 2045 is the learners who are currently sitting in the elementary, junior and senior high schools as well as those who are sitting in the College [1].

According to [16], the generation that is responsible for continuing the national aspiration in that period was very productive, precious and valuable. So that, we need to educate them well to be a qualified generation, characterised humans who are smart and competitive in facing the demography bonus.

The young generations have to be prepared by good characters because character decides moral quality and purpose of them while taking decision and attitude. The character is an integral part that should be built, so the young generation as the hope of the nation, as the generation that is responsible for deciding the future, must have attitude and intelligence based on the strong and right morality in building the nation efforts. Mindmap dimension of characterized Golden Generation 2045 focuses not only on practical and theoretical approaches (rational and empiric) but also essential and supra-rational approaches. Supra-rational logical approach consists of ethics and aesthetics. Those are what Mahatma Gandhi said "think rightly, act rightly and live rightly" [1].

In the school, character education could be implemented usingseveral strategies and approaches, like (1) integrating value and ethics of all lessons, (2) internalizing positive value taught by school people (headmaster, teachers and parents), (3) accustoming and practicing, (4) examples and icons (5) creating characterized atmosphere in the school, and (6) civilizing [17]. At home around family, character education could be implemented by modeling, loving, being disciplined and responsible.

\section{Concepts of Q-Time (Quality Time)}

Quality time is the time that is enjoyed together with the loved ones, such as family and friends, to do meaningful and useful activities or things, for example, to know each other, understand each character and even share opinions. In general, this moment is perfect for dads who spend less time with their family because of their work [18]. According to the Cambridge dictionary [19], Q-Time (Quality time) is time that you spend with someone, giving them your full attention because you value the relationship

Example: He spends quality time with his children every day. It means, he takes the quality time to gather with his children every day [19].

\section{E. Relevant Concepts with Problems Studied}

So far, there has been no officially programming from the government to every household to implement non-formal education within the family. the concepts which are relevant to this idea is that parenting education is held by private institutions, such as the parenting club, nabawiyyah parenting, griya parenting Indonesia, and others organized independently. Differentiate with those concepts, 1 Hour Q-Time concept will create a unique well-cultures if the government realizing time by time without drawing payments. This concept will reach large aspects of supervision and publication.

\section{F. Previous problem solving}

The solutions previously offered are preventive and curative efforts. Some of the preventive efforts that have been offered are BPMPAKB/Badan Pemberdayaan Masyarakat, Perempuan, Anak, dan Keluarga Berencana (Society and Women Empowerment Agency for Children and Family Planning). Pontianak City Government has conducted Children Development and Youth Delinquency Management activities by inviting parents and their children and involving Forum Anak (Kids Forum) for Pontianak city area [20].

Indonesia has built some rehabilitation places for drug addicts such as Lido (Campus Unitra), Baddoka (Makassar), and Samarinda under the supervision of [7] (National AntiNarcotics Agency). In this rehabilitation, the addicts follow various programs including therapeutic communities (TC), 12 steps (twelve steps, religious approach, etc.) [7].

Based on the facts, the number of juvenile delinquencies both of children and adolescences, from cases statistics of sexual violence, free sex, and illegal drugs increased higher and higher. These facts showed that the preventive and curative efforts from the government are not maximal. Rehabilitation, socialization, preventing children and adolescence juvenile delinquencies did not hold in the same time and totality in all areas of Indonesia. It was mentioned [21] that rehabilitation targets in 2016 were 200.000 patients, increasing one hundred percent from the previous year. Whereas, the number of addicted drugs based on Komjen Pol Budi Waseso, head of BNN [7] in 2015 reached 5.6 million people [22].

\section{G. Juvenile Delinquencies of Children and Adolescent}

Juvenile delinquencies problems of children and adolescents become the one of the crucial issues that must be noticed by all members of society in Indonesia. The happening situation of children and adolescent is very complex. The juvenile delinquencies such as pornography, abortion, free sex, drugs, bullying, and the other acts increase year by year. Natonal Commision of Children Protection (Komnas Anak) noted that in 2014 there were 89 suicides cases. Nine cases happened to children aged 5-10 years old, 39 cases happened to children aged 12-15 years old, and 27 cases happened to children aged 15 years old (www.nasinal.sindonews.com). Ironically, a 14-years old girl was raped then killed by 14 boys from Bengkulu in 2016 due to pornography addiction [8].

There are several factors which bring about juvenile delinquencies of children and adolescents. The factors are the unconducive environment, without communication and harmonization among them. According to the database of KPAI [3], from 3682 correspondents, most of them answered that most of the violence is from family and environment (see the appendixes). Among the ironic cases, KPAI [3] in May 2015 saved five childrenassumed that they are neglected by the family in Bekasi [22]. Besidest, there was no effective preventive efforts from family to anticipate the delinquency of 
children and adolescents. The phenomenon of Indonesia Gold 2045, twenty-seven years later can be a key of opportunity or even a disaster for the nation of Indonesia. Depending on how the children and adolescent as the main population component prepare to deal with this phenomenon. One of the main problems is the lack of government attention to proclaim the education within the family. This case also causes households in Indonesia to waive the family's active role in shaping the quality generation.

\section{H. Children and Adolescents Role in facing Golden Indonesia 2045}

Children and teenagers are a golden age. They have several advantages, including being able to think critically and creatively and have strong physical power. They are the agents of change. They are the next generation of the nation who aspire to be able to advance the nation and state.

According to the head of $B K K B N$ [6], Surya Chandra Surapaty, golden generation is a generation that in 2045, when Indonesia will enter the age of 100 years of independence, will be 35-54 years old. This generation stands on productive age, so they can be expected to be continuing the nation aspiration. Golden generation is expected to be a smart comprehensive generation, i.e. productive, innovative, and peaceful in social interaction, healthy and make healthy in nature interaction and superior civilisation. This generation is assumed holding essential roles in 2045, especially the pupils who are in the elementary, junior and senior high schools nowadays, and also the pupils who have just registered in the university and college [1].

To realize the golden generation in the golden anniversary of Indonesia independence day in 2045, BKKBN [6] launched 4 programs of activities (jatim.bkkbn.go.id), namely: 1) Family Development Program, 2) Genre Program (Generation Planning), 3) Elderly respite, 4) family empowerment program through UUPKS group (Usaha Peningkatan Pendapatan Keluarga Sejahtera/Improvement of Prosperous Family Income), and 5) Program of Being Great Parents.

\section{The Role of Parents in Educating and Creating the Golden Generation}

The nation crisis is a human resource crisis, especially the character crisis. The character is a relatively permanent behaviour that is either good or bad. Generation 2045 called "character of a golden generation" must have positive attitude, essential mind set, normative commitment, and abilities competence, and based on IESQ [1]. However, what is often forgotten from the essence of character education is the first environmental factor, namely the family. The character of the nation children is first formed through the family. The nation will be weak if the household or a family is fragile and weak. If the family environment is good, undoubtedly they have a superior character and quality as well.

In the family, the form of implementation of character education according to [23]:
- Often expressing love and affection to the child. It will form the character of a child who loves peace and love the homeland

- Being a good listener so a child will has an honest, communicative and friendly attitude;

- Teaching children the rules so that they will be a disciplined and responsible person.

- Teaching the children what is right, what is wrong depends on religion, rules in the life of the nation so that they will be religious and having spirit of nationalism

- Giving an understanding to the children that everyone is different, and they do not have to be like someone else. The goal is that they have an attitude of tolerance, caring and appreciation for the others.

- Giving good exemplary such as honesty, trustworthy, responsibility, respect, integrity, empathy and so on.

According to the Commissioner for Cybercrime and Pornography of the Indonesian Child Protection Commission, Arvianti [3], the family is the primary protector for children and adolescents from the influence of radicalism and terrorism. The family is also a shelter for children from fear and anxiety [24]

. From this prosperous family, a harmonious, peaceful, just, and prosperous society as the ideals and goals of national development can be realized.

To well implement these ideals and goals to be implemented, husband and wife play a major role in realizing a happy and prosperous family. They need to increase knowledge and understanding of how to foster family life in the guidance of religion and guidance of life in the community and state.

Thus, it is expected that each family member, especially husband and wife, can create the stability of household life which is full of peace and tranquility [25]. One way that parents can do in preparing the generation of Indonesia gold is the movement of 1 Hour Q-Time.

\section{IMPLEMENTATION OF 1 HOUR Q-TIME}

\section{A. Concept of 1 Hour Q-Time}

According to [26] from a psychological aspect, the family is a group of people who live together and each of member feels connected hearts, so all of them influence, take care and give up each other's. This definition makes us conclude that a family has created the activities which influencing and caring each other. It means that the qualified-time with family needs roles' of all family members. 1 Hour Q-Time concepts can handle all activities both influencing and caring in order to build the harmony family, especially in character building for children, in Table 2.

In psychological studies, there are times that the brain can accept information well. In this time, our frequency brainwave is theta with $4-8 \mathrm{~Hz}$, it is the time before going to sleep. This frequency indicates that mind-activities are 
subconscious. It can accept the information and memorize well [27]. Furthermore, if 1 Hour Q-Time could be applied at night before going to sleep, it will be more effective, because the subconscious condition will accept advises, information and stories well. For example, the 1 Hour Q-Time of family harmony movement takes place from 20:00 to 21:00 on some considerations, among others, (1) most children of parents are already at home after school and work, (2) it is presumed that at 20.00-21.00 children and parents have finished doing prays magrib and isha' (3) most of the family before 20:00 to 21:00 have dinner, (4) generally, at 18:00 to 19:30 children are reading Quran and studying, so that at 20:00 children have already done school dependent responsibilities.

Actually, the concept of 1 Hour Q-Time is a suggestion for minimum and ideal time and to gather all family members. If the application of 1 Hour Q-Time is more than 1 hour or 60 minutes, it is not a problem. Even though 1 hour is not enough to finish the family's problem, it is better to take more time than 1 hour.

1 Hour Q-Time is a family harmony movement to prepare the generation of Golden Indonesia 2045. Here is an analysis of movement characteristics of 1 Hour Q-Time [28], in Table 3.

According to [29], to give the advices well, the implementation should pay attention to several things, namely (1) using good words and languages politely and easy to understand, (2) not offending children, (3) using the words by considering the children's ages, characteristics, ability and position (4) considering the right time to give advice, (5) reminding and awakening the child, not impose and indoctrinateing so that the children always behave in a moral manner even if their parents are not at home, aand (6) inculcate the value of cleanliness, social value, scientific value, democracy value, responsibility value, and exemplary value .

TABLE II. HERE IS THE CONCEPT OF 1 HOUR Q-TIME.

\begin{tabular}{|l|l|l|l|}
\hline No & Subject & Duration & \multicolumn{1}{c|}{ Description } \\
\hline 1 & $\begin{array}{l}\text { Parents } \\
\text { and } \\
\text { children }\end{array}$ & 5 minutes & $\begin{array}{l}\text { Parents and children prepare a gathering } \\
\text { place to carry out 1 Hour Q-Time. As much } \\
\text { as possible the use of gadgets is minimized if } \\
\text { it is necessary, the mobile phone is turned } \\
\text { off. }\end{array}$ \\
\hline 2 & Parents & $\begin{array}{l}15 \\
\text { minutes }\end{array}$ & $\begin{array}{l}\text { Parents begin to talk to children about the } \\
\text { things they like and aspire to, for example is } \\
\text { Rio Haryanto's latest news. This method is } \\
\text { expected to make children feel comfortable. } \\
\text { When the children begin to feel comfortable, } \\
\text { they will tell their own problems. }\end{array}$ \\
\hline 3 & Children & $\begin{array}{l}15 \\
\text { minutes }\end{array}$ & $\begin{array}{l}\text { The children tell the activities of that day } \\
\text { and express the feelings and problems they } \\
\text { faced. }\end{array}$ \\
\hline 4 & Parents & $\begin{array}{l}15 \\
\text { minutes }\end{array}$ & $\begin{array}{l}\text { Parents give solutions based on the problems } \\
\text { faced by children, to increase the children's } \\
\text { motivation. }\end{array}$ \\
\hline 5 & Parents & $\begin{array}{l}10 \\
\text { minutes }\end{array}$ & $\begin{array}{l}\text { Parents close the meeting by telling inspiring } \\
\text { stories and full of wisdom from icons, like } \\
\text { messengers, previous people, heroes, } \\
\text { achieved young people, and good leaders } \\
\text { based on the problem they face, so the } \\
\text { children can take lessons from that stories. }\end{array}$ \\
\hline
\end{tabular}

TABLE III. TABle Characteristics of 1 Hour Q-Time Program

\begin{tabular}{|c|c|c|}
\hline Aspect & Description & Expected Results \\
\hline Solidarity & $\begin{array}{l}\text { Parents ask the children } \\
\text { developmental } \\
\text { condition. } \\
\text { express the feelings and } \\
\text { problems they face. } \\
\text { Parents can warm the } \\
\text { atmosphere up by joking } \\
\text { and telling stories. }\end{array}$ & $\begin{array}{lrr}\text { Children and } & \text { parents } \\
\text { establish a } & \text { good } \\
\text { communication. } & \end{array}$ \\
\hline $\begin{array}{l}\text { Honesty, } \\
\text { communicative } \\
\text { friendliness, and } \\
\text { tolerance }\end{array}$ & $\begin{array}{l}\text { 1 Hour Q-Time program } \\
\text { presents the father and } \\
\text { mother who become } \\
\text { 'friends' of children so } \\
\text { that children can be } \\
\text { comfortable with the } \\
\text { parents. }\end{array}$ & $\begin{array}{l}\text { Both parents and children } \\
\text { can avoid worry and be able } \\
\text { to solve the problems } \\
\text { together. }\end{array}$ \\
\hline $\begin{array}{l}\text { Exemplary, } \\
\text { caring, curiosity. }\end{array}$ & $\begin{array}{l}\text { When parents provide } \\
\text { solutions, they can } \\
\text { convey a story of } \\
\text { wisdom that can be a } \\
\text { role model for children. } \\
\text { Modeling is also sourced } \\
\text { from the behavior of } \\
\text { parents. }\end{array}$ & $\begin{array}{l}\text { Parents become the role } \\
\text { models for children, } \\
\text { whether they meet parents } \\
\text { or not. By such } \\
\text { communication, parents are } \\
\text { involved in it. Children's } \\
\text { curiosity grow after } \\
\text { listening to the inspirational } \\
\text { stories. }\end{array}$ \\
\hline
\end{tabular}

\section{Analyzing the Concept of One Qualified Hour}

\section{DEVELOPMENT METHODS}

The method undertaken in the implementation of this program consists of three stages, namely (1) socialization, (2) implementation, and (3) evaluation.

\section{A. Socialization phase}

The coordination meetings are held among the implementing members first before being socialized to the public. After all drafts have been mastered by all the implementing members, there will be a socialization and an official proposal to the local government started from RT and RW, hamlet, village, to the district and city government regarding the concept of 1 Hour Q-Time. After getting the permission from the government, socialization is conducted in the community, both through $P K K$ (Family Welfare Program) organization and local KUA (Religion Matter Office) institutions with the agenda of socialization of 1 Hour Q-Time in a pre-marital education program for married couples. The publications are executed through social media, such as websites, Facebook, Twitter, Instagram, YouTube, etc to support the socialization stage.

\section{B. Implementation Phase}

Several strategic steps to implement 1 Hour Q-Time to prepare the Golden Generation of Indonesia 2045, including:

- Inviting to watch scientific and educational television so that it can be used as discussion materials between parents and children in doing 1 Hour Q-Time.

- Creating a Family Parenting Handbook in Indonesia $(B P P K)$. This book is a general guide for every family and couple to marry. This book is prepared by the Ministry of Education and Ministry of Religious Affairs. 
- Designing a parenting website of 1 Hour Q-Time and its applications that can be accessed on mobile phones via playstore and the others. Disseminating these applications on the internet for free to be downloaded by the public.

- Publishing and socializing the official 1 Hour Q-Time through social media, such as Facebook, Twitter, Instagram, Youtube, and so on.

- Holding seminars and workshops of 1 Hour Q-Time in a pre-marriage education program for married couples.

- There is a parenting forum in every $R T$ (neighborhood) $/ R W$ (hamlet) which is conducted monthly by citizens to discuss the children's problems in the neighborhood or discuss about parenting.

- Choosing an exemplary parent of 1 Hour Q-Time. This election is carried out by the Family Planning Coordinating Board $(B K K B N)$ [6] intended for the public to be published as a means of education and motivation for couples who have and will get married.

- The 1 Hour Q-Time program cannot be applied directly to all over Indonesia. This program will first be conducted in the city of Malang as a city that once bore a child-friendly city on Tuesday, August 11, 2015 [30]. When the 1 Hour Q-Time program can be successfully implemented in Malang city, then the program can be applied to the city that has the same characteristics with the city of Malang. So little by little, all regions in Indonesia are able to hold the 1 Hour Q-Time program.

- Establishing parenting forums at the RT/RW level to discuss the development of children and adolescents in the neighborhood area of residence along with the implementation of 1 Hour Q-Time in the region.

- Parents and children run the 1 Hour Q-Time program for one hour every day.

\section{Evaluation Phase}

The purpose of the evaluation is to know the goals of the objectives of a program by knowing the implementation of program activities. Evaluation activities are not only carried out at the end of the program but also can be executed at the beginning and in the middle of progress. The evaluation phase is conducted periodically by the government, experts, and each family. The evaluation stage consists of (1) preparation, (2) implementation of the evaluation program, and (3) monitoring [31] supported by the data (questionnaires, interviews, recordings, pictures, video, and statistic website and social media of Hour Q-Time 1). It takes experts and researchers to further examine the effectiveness of 1 Hour Q-Time. Furthermore, each family will be evaluated through a questionnaire of citizens' aspirations to be followed up by the government.

\section{Who CAN ASSist IN IMPLEMENTING Q-TIME PROGRAMS 20-21 BASED ON THEIR OWN DESCRIPTION ROLE}

The ones who are expected to assist and support the implementation of the 1 Hour Q-Time programs are as follows:

\section{A. Ministry of Communication and Information}

The Ministry of Communication and Information determines the rules of broadcasting strictly, so both private and state broadcasting companies only broadcast educated and qualified programs. The Ministry of Communication and Information also supervises and decides all stations of television to present scientific and educative programs. Besides, the government is expected to be able to socialize 1 Hour Q-Time program via all media; it could be an advertisement on television or official government website.

\section{B. Ministry of Education and Culture and Ministry of Religious Affairs}

The Ministry of Education and culture and the Ministry of Religious Affairs will work together to publish Family Parenting Guiding Book (BPPK). It will be a guiding book that everyone and every couple must-have. This guiding book has contents of husband and wife harmony, the ways to build a communication with the children, the ways to understand children psychology and the others.

\section{Indonesian Child Protection Commission (KPAI) and Ministry of Social Affairs}

The Ministry of social affairs and KPAI [3] socialize and supervise the implementation of 1 Hour Q-Time program organized in every district. Besides, they have to do evaluation and fixation of both rules and implementation continuously.

\section{Religion Matters Office (KUA)}

Religion Matters Office (KUA) has a role to hold the parenting education program before marriage as one of the marriage requirements for all couples who register to marry. Parenting education program can support the implementation of 1 Hour Q-Time program because the couples who want to marry will be educated through parenting training for their children and families.

\section{E. Leader of Neighborhood (RT) and Hamlet $(R W)$}

The leader of neighborhood can make parenting forum once in a month for discussing the children's growth and all about parenting.

\section{Parents and Children}

Parents and children do 1 Hour Q-Time program every day frequently.

\section{The Advantages of 1 Hour Q-Time Program}

Based on the analysis of the characteristics of 1 Hour QTime Program, there are some positive effects from many sides. Especially, this program has several advantages as follows: 
- As parents' control for children activities.

- Building a good communication among parents and children;

- Children have media for sharing stories and problem; Tadkiroatun Musfiroh [27], it is mentioned that telling stories has several advantages, (1) to help shaping excellent characteristic and attitude (2) to fulfill imagination needs, and (3) to open the knowledge.

- Parents understand the children's condition, so they can help solving the problems and

- Easy to apply.

\section{CONCLUSION}

Based on the description of the analysis and synthesis, it can be concluded several things, (1) when Indonesia will enter the age of 100 years of independence, the generation that is at the productive age is currently occupying the levels of elementary, junior high, junior and university, (2) One of the ways parents can do in preparing the Golden Generation of Indonesia free from juvenile delinquency is 1 Hour Q-Time movement. 1 Hour Q-Time is a deliberate preventive effort of children and adolescents to prepare a noble-born Indonesian Generation of 2045, and (3) in the implementation, parents take an hour to talk to their children, listen to their complaints and problems, and give a wisdom-based solution. This program creates warmth and harmony between families, this program serves as a control of all activities of children to avoid the things that plunge. In order to be effective, it needs strategic and cooperated steps from the government, experts, and the community. Media that can support the implementation of this program are online media, guidebooks, websites, and applications, as well as an agenda proclaimed in the premarriage education program.

Some suggestions that the authors provide to the related issues are: (1) For the government, 1 Hour Q-Time should be the focus of preventive efforts to prevent the delinquency of children and adolescents to prepare the Generation of Indonesia 2045. The existence of cooperation with religious experts, parenting, and broadcasting in this program is absolutely necessary, (2) Begin to conduct further research in order to make the concept more mature to apply, and (3) The public should be aware of the responsibility to safeguard and educate their children by supporting and running the 1 Hour Q-Time program to prepare the Golden Generation of Indonesia 2045.

\section{REFERENCES}

[1] B. Manullang, "Grand Desain Pendidikan Karakter Generasi Emas 2045," J. Pendidik. Karakter, vol. 3, no. 1, 2013.

[2] C. Campbell, "Juvenile Delinquency.," Am. Polit. Sci., vol. 2, no. 4, 2013.

[3] KPAI, "Keluarga Pelindung Utama Anak dari Pengaruh Radikalisme," 2017. [Online]. Available: http://www.kpai.go.id/berita/keluargapelindung-utama-anak-dari-pengaruh-radikalisme/\#.

[4] I. Aroma and D. Suminar, "Hubungan Antara Tingkat Kontrol Diri dengan Kecenderungan Perilaku Kenakalan Remaja," J. Psikol. Pendidik. dan Perkemb., vol. 1, no. 2, pp. 1-6, 2012.
[5] BPS, "Statistik Kriminal 2014.," 2014. [Online]. Available: https://microdata.bps.go.id/mikrodata/index.php/citations/83.

[6] BKKBN, "Membangun Generasi Emas Berbasis keluarga Melalui Program KKBPK," 2016. [Online]. Available: http://jatim.bkkbn.go.id/membangun-generasi-emas-berbasis-keluargamelalui-program-kkbpk/.

[7] BNN, "Tahap-Tahap Pemulihan Pecandu Narkoba.," 2013. [Online]. Available:

http://dedihumas.bnn.go.id/read/section/artikel/2012/08/24/514/tahaptahap-pemulihan-pecandu-narkoba.

[8] Liputan 6, "Psikolog: Kasus Seperti Yuyun Terjadi karena Kecanduan Pornografi," $2016 . \quad$ [Online]. Available: http://news.liputan6.com/read/2501381/psikolog-kasus-seperti-yuyunterjadi-karena-kecanduan-pornografi.

[9] Sriyanto, A. Aim, Z. Asmawi, and M. Enok, "Perilaku Asertif dan Kecenderungan Kenakalan Remaja Berdasarkan Pola Asuh dan Peran Media Massa," J. Psikol., vol. 41, no. 1, pp. 74-88, 2014.

[10] P. N. Nindya and R. Margaretha, "Hubungan antara kekerasan emosional pada anak terhadap kecenderungan kenakalan remaja," $J$. Psikol. Klin. dan Kesehat. Ment., vol. 1, no. 2, pp. 1-8, 2012.

[11] H. Harvard., "Perkembangan Kependudukan dan Pembangunan Keluarga," $2009 . \quad$ [Online]. https://www.hsph.harvard.edu/population/policies/indonesia.population 09.pdf.

[12] S. Landr, "Parent Support Programs and Early Childhood Development: Comments on Goodson, and Trivette and Dunst1," 2008.

[13] J. Rakhmat, Psikologi Komunikasi. Bandung: Penerbit PT Remaja Rosdakarya, 2005.

[14] R. H. A. Tabrani., Membangun Disiplin Karakter Anak Bangsa. Jakarta: PT. Pustaka Dinamika, 2002.

[15] F. Rokhman, M. Hum, and A. Syaifudin, "Character Education For Golden Generation 2045 (National Character Building for Indonesian Golden Years)," Procedia-Social Behav. Sci., vol. 141, pp. 1161-1165, 2014.

[16] M. E. Wibowo, "Menyiapkan Bangkitnya Generasi Emas Indonesia," 2012. .

[17] A. Pristine and E. Suryani, "Implementasi Pembentukan Karakter Budi Pekerti di Smp Negeri 1 Tanggul Jember," J. Pendidik. Karakter, vol. 5, no. 1, pp. 82-89, 2016.

[18] Dorar Info, “Arti Quality Time.," 2014. [Online]. Available: http://www.dorar.info/2014/04/arti-quality-time.html.

[19] Cambridge University Press, "Quality Time," 2016. [Online]. Available: http://dictionary.cambridge.org/dictionary/english/qualitytime.

[20] KLA, "Pembinaan Anak dan Penanggulangan Kenakalan remaja di Kota Ponianak." [Online]. Available: http://www.kla.or.id/index.php?option=com_content\&view=article\&id $=1697$ :pembinaan-anak-dan-penanggulangan-kenakalan-remaja-dikota-pontianak\&catid=5 inak\&Itemid $=65$

[21] A. News., "Mensos: s fokus penanganan narkoba dan pornografi.," 2015.

[22] Kompas, "Buwas: Pengguna Narkoba di Indonesia Meningkat hingga 5,9 Juta Orang," 2016. [Online]. Available: http://regional.kompas.com/read/2016/01/11/14313191/Buwas.Penggu na.Narkoba.di.Indonesia.Meningkat.hingga.5.9.Juta.Orang.

[23] S. Bariroh, "Strategi dan Implementasi Pendidikan Karakter dalam Keluarga." [Online]. Available: http://mandirinews.com/?p=4605.

[24] M. R. Dadds, P. M. Heard, and R. M. Rapee, "The role of family intervention in the treatment of child anxiety disorders: Some preliminary findings," Behav. Chang., vol. 9, no. 3, pp. 171-177, 1992.

[25] D. Suparno, "Cetak Generasi Emas Dimulai dari Keluarga yang Berkualitas," $2015 . \quad$ [Online]. Available: http://www.kompasiana.com/nfkaafi/cetak-generasi-emas-dimulai-darikeluarga-yang-berkualitas_55c4dacd6f7a613924afa488.

[26] S. Falah, Parents Power Membangun Karakter Anak melalui Pendidikan Keluarga. Jakarta: Republika, 2014. 
[27] K. Kamilin and D. Asri, "Relaxation-Story Before Sleeping (R-Sbs): Pemanfaatan Instrumen Relaksasi (At-Tarwih) Berbasis Kisah Teladan (Al-Amtsal) sebagai Media Internalisasi Nilai-Nilai Qur'ani pada Anak," 2013.

[28] F. Ummah and M. Shovi, "Q-Time 20-21: Gerakan Keharmonisan Keluarga Pukul 20.00-21.00 sebagai Upaya Preventif Kenakalan Anak dan Remaja Berdasarkan Kajian Surah Luqman Ayat 12-19," 2016.
[29] H. Muchtar, Fikih Pendidikan. Bandung: PT Rosdakarya, 2012.

[30] Malangkota, "Pemkot Malang Serius Wujudkan Kota Ramah Anak," 2016.

[31] Al-Qusairi and M. Abdul, "Langkah-langkah Evaluasi Program,” 2014. 